\title{
Detection of methylation of the RAR- $\beta$ gene in patients with non-small cell lung cancer
}

\author{
XUDONG ZHAO $^{1 *}$, NIANFEI WANG ${ }^{2 *}$, MINGJUN ZHANG $^{2}$, \\ SHAOLI XUE ${ }^{3}$, KAIHU SHI ${ }^{1}$ and ZHENDONG CHEN ${ }^{2}$ \\ Departments of ${ }^{1}$ Cardiothoracic Surgery, and ${ }^{2}$ Oncology, Second Affiliated Hospital of Anhui Medical University, \\ Hefei, Anhui 230601; ${ }^{3}$ Department of Biotechnology, Anhui Medical University, \\ Hefei, Anhui 230032, P.R. China
}

Received August 30, 2011; Accepted November 22, 2011

DOI: $10.3892 / \mathrm{ol} .2011 .527$

\begin{abstract}
The aim of this study was to detect methylation of the RAR- $\beta$ gene in tissues from non-small cell lung cancer (NSCLC) patients. The methylation of the RAR- $\beta$ gene in DNA from 80 cases with NSCLC and corresponding non-malignant tissues was tested using methylation-specific polymerase chain reaction (PCR; MSP). The results showed that the total frequency of RAR- $\beta$ methylation was significantly higher in lung cancer tissues compared to the corresponding non-malignant tissues (57.5 vs. 17.5\%) $(\mathrm{P}<0.01)$. However, no significant difference was found in various clinical stages and types of lung cancer $(\mathrm{P}>0.05)$. A significant difference was observed in the various pathological types $(\mathrm{P}<0.05)$. $\mathrm{RAR}-\beta$ gene methylation is closely correlated with the development process of NSCLC, particularly squamous cell carcinoma.
\end{abstract}

\section{Introduction}

Lung cancer is the most common malignant tumor originating in the lung, and increasing numbers of individuals suffer from the disease every year. The morbidity and mortality rates of lung cancer have been among the highest of all malignant tumors $(1,2)$. Non-small cell lung cancer (NSCLC) accounts for $80 \%$ of all lung cancers.

Methylation appears during cell transformation and, consequently, may serve as the biological marker for early diagnosis.

Correspondence to: Professor Kaihu Shi, Department of Cardiothoracic Surgery, Second Affiliated Hospital of Anhui Medical University, Hefei, Anhui 230601, P.R. China

E-mail: shikaihu@gmail.com

Dr Zhendong Chen, Department of Oncology, Second Affiliated Hospital of Anhui Medical University, Hefei, Anhui 230601, P.R. China

E-mail: chenzhendong@csco.org.cn

*Contributed equally

Key words: gene, methylation, non-small cell lung cancer
Findings of studies have shown that RAR- $\beta$ was absent in varying degrees in multiple malignant tumors. Investigators have indicated that the decrease of RAR- $\beta$ expression is associated with the formation of a tumor (3). It is well known that RAR- $\beta$ is methylated in NSCLC lesions (4). RAR- $\beta$ has also been found to be methylated in plasma from patients with lung cancer (5), and was even detected in bronchial aspirates from patients with suspected lung cancer (6). Studies conducted in the past decade have reported the presence of RAR- $\beta$ methylation in lung cancer.

On the basis of the present status of global investigations on lung cancer and related genes, methylation-specific polymerase chain reaction (PCR; MSP) was applied in this study to assay methylation of the RAR- $\beta$ gene promoter in lung cancer and corresponding non-malignant tissues, which provided the basis for diagnosis of NSCLC.

\section{Materials and methods}

Specimen collection. A total of 80 patients (68 males and 12 females) with an average age of 59.41土9.67 years (range, 32-78) were enrolled in this study. This cohort comprised 45 squamous cell carcinoma and 35 adenocarcinoma patients, as well as other types of carcinoma. The patients underwent surgical excision in Anhui Province Hospital (China) and the diagnosis was pathologically confirmed. According to TNM staging criteria, the patients were classified as stage $0(n=1)$, I ( $=29)$, II $(n=37)$, III $(n=13)$ and IV $(n=0)$. A total of $1 \mathrm{~cm}^{3}$ of lung cancer and another $1 \mathrm{~cm}^{3}$ of normal tissues, $3 \mathrm{~cm}$ away from the cancer tissues, were collected from each patient. Specimens were preserved in liquid nitrogen.

DNA extraction. DNA was extracted from cancer tissues and paratumor tissues using a phenol-chloroform method.

Detection of RAR- $\beta$ methylation. MSP was used to detect RAR- $\beta$ methylation, as described in the literature (7). The rationale was that the base $\mathrm{C}$ shifted to $\mathrm{U}$ under the action of natrium bisulfurosum following DNA degeneration and melting; however, methylated $\mathrm{C}$ did not shift. According to this rationale, 2 pairs of different primers were designed for PCR amplification in order to detect the differences. 
Table I. Results of RAR- $\beta$ methylation in tissues of lung cancers of various clinical parameters.

\begin{tabular}{|c|c|c|c|c|c|c|}
\hline Clinical parameter & $\mathrm{n}$ & Positive & Negative & Rate $(\%)$ & $\chi^{2}$ value & P-value \\
\hline \multicolumn{7}{|l|}{ Gender } \\
\hline Male & 68 & 41 & 27 & 60.3 & 0.446 & 0.504 \\
\hline Female & 12 & 6 & 6 & 50.0 & & \\
\hline \multicolumn{7}{|l|}{ Cigarette use } \\
\hline Yes & 61 & 40 & 21 & 65.6 & 4.325 & 0.048 \\
\hline No & 19 & 8 & 11 & 42.1 & & \\
\hline
\end{tabular}

Table II. Comparison of results of RAR- $\beta$ methylation between stages 0-I and II-IV lung cancer tissues.

\begin{tabular}{|c|c|c|c|c|c|c|c|}
\hline \multirow[t]{2}{*}{$\begin{array}{l}\text { Clinical } \\
\text { stage }\end{array}$} & \multicolumn{2}{|c|}{$\begin{array}{l}\text { Methylation of } \\
\text { RAR- } \beta \text { gene }\end{array}$} & \multirow[t]{2}{*}{$\begin{array}{l}\text { Detection } \\
\text { rate }(\%)\end{array}$} & \multirow[t]{2}{*}{$\chi^{2}$ value } & \multirow[t]{2}{*}{ P-value } & \multirow[t]{2}{*}{ OR } & \multirow[t]{2}{*}{$95 \% \mathrm{CI}$} \\
\hline & Positive & Negative & & & & & \\
\hline $0-\mathrm{I}$ & 16 & 14 & 53.3 & & & & \\
\hline II-IV & 30 & 20 & 60.0 & 0.341 & 0.559 & 0.762 & $0.306-1.900$ \\
\hline Total & 46 & 34 & 57.5 & & & & \\
\hline
\end{tabular}

OR, odds ratio; CI, confidence interval.

DNA modification. DNA samples $(50 \mu \mathrm{l})$ were added to $5.5 \mu \mathrm{l}$ of fresh $3 \mathrm{~mol} / 1$ sodium hydroxide $(\mathrm{NaOH})$ followed by a 30 -min water bath incubation at $42^{\circ} \mathrm{C}$. Then, $30 \mu \mathrm{l}$ of fresh $10 \mathrm{mmol} / 1$ hydroquinone and $510 \mu \mathrm{l}$ of fresh $3.9 \mathrm{~mol} / 1$ sodium bisulfite (Sigma, St Louis, MO, USA) were added. Paraffin wax was then dropped to protect it from light exposure. Eventually, the resulting products underwent a water-bath at $55^{\circ} \mathrm{C}$ for $16 \mathrm{~h}$.

DNA purification. The Wizard DNA purification system (Promega, Madison, WI, USA) was used, and was operated according to the manufacturer's instructions. Following the formation of a resin-bond, $\mathrm{NaOH}$ desulfonation and ethanol precipitation, DNA was dissolved in $50 \mu 1 \mathrm{TE}$ buffer solution.

Primer design. The primers used in this study were: RAR- $\beta$ methylation: upstream primer: 5'-TCGAGAACGCGAGC GATTCG-3', downstream primer: 5'-GACCAATCCAACCG AAACGA-3'; product: $146 \mathrm{bp}$; annealing temperature: $58^{\circ} \mathrm{C}$.

RAR- $\beta$ non-methylation: upstream primer: 5'-TTGAGA ATGTGAGTGATTTGA-3'; downstream primer: 5'-AACCAA TCCAACCAAAACAA-3'; product: $146 \mathrm{bp}$; annealing temperature: $58^{\circ} \mathrm{C}$.

Internal standard: upstream primer: 5'-CAACTTCATCCA CGTTCACC-3'; downstream primer: 5'-GAAGAGCCAAGGA CAGGTAC-3'; product: $268 \mathrm{bp}$; annealing temperature: $59^{\circ} \mathrm{C}$.

The primers were synthesized by Sangon Biotech Co., Ltd (Shanghai, China).

PCR process. The PCR reaction system $(25 \mu \mathrm{l})$ included Q solution $(5.0 \mu \mathrm{l})$, buffer $(2.5 \mu \mathrm{l}), 10 \mathrm{mmol} / \mathrm{l}$ deoxyribonucleotide triphosphates (dNTPs; $0.5 \mu \mathrm{l}), 20 \mu \mathrm{mol} / \mathrm{l}$ primer $(0.5 \mu \mathrm{l})$ each,
HotStarTaq enzyme (Qiagen, 0.75 units) and modified DNA $(5.0 \mu \mathrm{l})$. DNA from the peripheral blood of normal individuals treated, or not, with Sss1 enzyme was used, respectively, as positive controls of methylation and non-methylation. PCR was initially run at $95^{\circ} \mathrm{C}$ for 15 -min denaturation and then 35 cycles of $50 \mathrm{sec} / 94^{\circ} \mathrm{C}$ for denaturation and $50 \mathrm{sec} / 72^{\circ} \mathrm{C}$ for annealing, followed by $10 \mathrm{~min} / 72^{\circ} \mathrm{C}$ elongation. The amplification products were stored at $4^{\circ} \mathrm{C}$.

Analysis of PCR products. PCR amplification products $(8 \mu \mathrm{l})$ were stained with ethidium bromide and electrophoresed in a $2.0 \%$ agarose gel. An amplified strip specific for methylation primer suggested the presence of methylation in the specimen.

Statistical analysis. Epi6 Software was used to establish the database. SPSS 11.0 Software was applied for statistical analysis. The methylation rate was defined as the ratio of methylation specimens to total specimens and was expressed as a percentage. The methylation rate was compared by a $\chi^{2}$ test.

\section{Results}

Comparison of results of RAR- $\beta$ methylation between lung cancer and paratumor tissue. A total of 80 specimens each for the lung cancer and paratumor tissues were assayed simultaneously. Methylation was detectable in 46 lung cancer and 14 paratumor specimens with a rate of 57.5 and $17.5 \%$, respectively. The difference was considered to indicate statistical significance $(\mathrm{P}<0.01)$.

Results of RAR- $\beta$ methylation in tissues of lung cancers in various clinical parameters. No statistical difference was 
Table III. Comparison of RAR- $\beta$ methylation between tissues of varying types of lung cancer.

\begin{tabular}{|c|c|c|c|c|c|c|c|}
\hline \multirow[t]{2}{*}{$\begin{array}{l}\text { Clinical } \\
\text { type }\end{array}$} & \multicolumn{2}{|c|}{$\begin{array}{l}\text { Methylation of } \\
\text { RAR- } \beta \text { gene }\end{array}$} & \multirow[t]{2}{*}{$\begin{array}{c}\text { Detection } \\
\text { rate }(\%)\end{array}$} & \multirow[t]{2}{*}{$\chi^{2}$ value } & \multirow[t]{2}{*}{ P-value } & \multirow[t]{2}{*}{ OR } & \multirow[t]{2}{*}{$95 \%$ CI } \\
\hline & Positive & Negative & & & & & \\
\hline $\begin{array}{l}\text { Peripheral } \\
\text { type }\end{array}$ & 18 & 16 & 52.9 & & & & \\
\hline $\begin{array}{l}\text { Central } \\
\text { type }\end{array}$ & 28 & 18 & 60.9 & 0.503 & 0.478 & 0.723 & $0.295-1.773$ \\
\hline Total & 46 & 34 & 57.5 & & & & \\
\hline
\end{tabular}

OR, odds ratio; CI, confidence interval.

Table IV. Comparison of RAR- $\beta$ methylation between lung cancer tissues of various pathological types.

\begin{tabular}{|c|c|c|c|c|c|c|c|}
\hline \multirow[t]{2}{*}{$\begin{array}{l}\text { Pathological } \\
\text { type }\end{array}$} & \multicolumn{2}{|c|}{$\begin{array}{l}\text { Methylation of } \\
\text { RAR- } \beta \text { gene }\end{array}$} & \multirow[t]{2}{*}{$\begin{array}{l}\text { Detection } \\
\text { rate }(\%)\end{array}$} & \multirow[t]{2}{*}{$\chi^{2}$ value } & \multirow[t]{2}{*}{ P-value } & \multirow[t]{2}{*}{ OR } & \multirow[t]{2}{*}{$95 \% \mathrm{CI}$} \\
\hline & Positive & Negative & & & & & \\
\hline $\begin{array}{l}\text { Squamous cell } \\
\text { carcinoma }\end{array}$ & 30 & 15 & 66.7 & & & & \\
\hline $\begin{array}{l}\text { Adenocarcinoma } \\
\text { and other cell types }\end{array}$ & 15 & 20 & 42.9 & 4.535 & 0.033 & 2.667 & $1.071-6.640$ \\
\hline Total & 45 & 35 & 56.3 & & & & \\
\hline
\end{tabular}

OR, odds ratio; CI, confidence interval.

found in the detection rate of RAR- $\beta$ gene methylation between the male and female NSCLC patients. The detection rate of RAR- $\beta$ methylation was significantly higher in the smoking group than that in the non-smoking group $\left(\chi^{2}=4.325, \mathrm{P}<0.05\right.$; Table I).

Results of RAR- $\beta$ methylation in tissues of lung cancers at various stages. No difference was found in the methylation rate of the RAR- $\beta$ gene between stage 0 -I and II-IV lung cancer tissues $\left(\chi^{2}=0.341, P>0.05\right.$; Table II).

Comparison of RAR- $\beta$ methylation between tissues of lung cancer of varying clinical types. No statistical difference was observed in the detection rate of RAR- $\beta$ gene methylation between the central and peripheral lung cancer tissues $\left(\chi^{2}=0.503, P>0.05 ;\right.$ Table III $)$.

Results of RAR- $\beta$ methylation in lung cancer tissues of various pathological types. The detection rate of RAR- $\beta$ methylation was significantly higher in the squamous cell carcinoma group than that in the adenocarcinoma group $\left(\chi^{2}=4.535, \mathrm{P}<0.05\right.$; Table IV).

\section{Discussion}

Pathogenesis of lung cancer is a complicated biological process involving multiple genetic and epigenetic changes. In recent studies, the role of the genetic mechanisms has been of increasing concern to global investigators. Although the methylation rate of some antioncogenes is low in NSCLC, combined detection of these genes may vastly improve the positive detection rate of tumors or prognostic judgment.

Currently, methylation of $\mathrm{CpG}$ islands in the promoter of certain antioncogenes and susceptible genetic polymorphisms are being further assayed and analyzed (8). This may inhibit genetic transcription, which is an approach regulating genetic expression in normal cells. However, abnormal methylation of antioncogenes occurs not only in the early stages of tumor development, but also throughout the disease, leading to the phenotypic expression of malignant tumors. Therefore, DNA methylation is considered to be a novel and promising marker of previous carcinogen exposure and carcinoma risk (9). RAR- $\beta$ methylation is associated with tumor differentiation and malignant transformation and is a potential antioncogene. The absence and decrease of RAR- $\beta$ expression are presented in human gastrointestinal, liver and cervical cancer, as well as other malignant tumors (10-12).

A number of studies have proven that methylation of the RAR- $\beta$ promoter affects numerous tumor-suppressing genes, which are subsequently silent and not expressed (13). Brabender (14) et al found that the majority of NSCLC patients with the expression of retinoic acid receptors and retinoid $\mathrm{X}$ receptors decreased, and also demonstrated that an abnormal expression of RAR- $\beta$ receptors in lung cancer tissues may be 
correlated with lung cancer. Other studies have shown that the abnormal methylation of the RAR- $\beta$ gene is an early and common change in a nude mouse model with lung cancer, induced by correlative environmental factor exposure (15).

In the present study, the detection rate of methylation of the RAR- $\beta$ gene exhibited significant differences between lung cancer and paratumor tissues, but no statistical differences among various stages or various clinical types, and was significantly higher in squamous cell carcinoma compared to adenocarcinoma and other types of cancer, which was consistent with previous studies. These results suggest that RAR- $\beta$ methylation in lung cancer tissues or specimens is an effective index for the diagnosis of various clinical types of lung cancer.

The relationship analysis of $R A R-\beta$ methylation in lung cancer tissues and various clinical parameters. Carcinogens in tobacco are known to be a considerable driver of NSCLC. In long-term smokers, genes, including p16, MGMT and RASSF1a, undergo methylation. The methylation rate is closely correlated with the smoking index and age at which smoking was initiated $(16,17)$. Whether the carcinogens in tobacco are a direct cause of gene methylation is not known. However, animal experiments have shown that the carcinogens in tobacco induce certain genes, such as DAPK and RASSF1a, that are methylated in mice (18). In the present study, the detection rate of RAR- $\beta$ methylation was significantly higher in the smoking group than that in the non-smoking group, which suggests that tobacco plays a potential role in gene methylation. Yanagawa et al have drawn the same conclusion (19).

Analysis of RAR- $\beta$ methylation detection in various clinical stages of NSCLC. We investigated whether or not the lung cancer gene methylation is correlated with TNM stage. Our results have not demonstrated that there is a causality between RAR- $\beta$ gene methylation and clinical stage. The methylation rate of NSCLC patients is slightly higher in stages II-III than in 0-I; however, there was no statistical difference in detection. We were unable to conclude from this experiment whether RAR- $\beta$ gene methylation could be used as an indicator of early diagnosis of lung cancer on account of our small sample size. It is expected that more definitive conclusions may be drawn when the sample size is increased, particularly in stages I-II of NSCLC patients.

Analysis of RAR- $\beta$ methylation detection in lung cancer tissues of various pathological types. Toulouse (20) et al successfully reduced their tumorigenicity in nude mice through the introduction of RAR- $\beta$ into RAR- $\beta$-negative lung cancer cells This result confirmed the RAR- $\beta$ gene as a squamous cell lung cancer tumor suppressor gene. In this study, all 80 cases of lung cancer were divided into different groups of squamous cell carcinoma, adenocarcinoma and other types of lung cancer, according to histological types. Through statistical analyses we found that the detection rate of RAR- $\beta$ methylation was significantly higher in the squamous cell carcinoma group than that in the adenocarcinoma group, and that RAR- $\beta$ gene methylation is more closely correlated with squamous cell carcinoma.
In conclusion, we believe that RAR- $\beta$ gene methylation is closely related to the development process of NSCLC. In future studies, we will carry out further research regarding the relationships between NSCLC gene methylation and histological types, as well as the degree of differentiation.

\section{Acknowledgements}

N.W. and X.Z. contributed equally to this work. We thank Wei Cao and Shouhui Chen for their technical assistance. This study was supported by grants from the Anhui Province Key Scientific Research Project (No. 07021017).

\section{References}

1. Veglia F, Vineis P, Overvad K, et al: Occupational exposures, environmental tobacco smoke, and lung cancer. Epidemiology 18: 769-775, 2007.

2. Alberg AJ, Brock MV and Samet JM: Epidemiology of lung cancer: looking to the future. J Clin Oncol 23: 3175-3185, 2005.

3. Poulain S, Lacomme S, Battaglia-Hsu SF, et al: Signalling with retinoids in the human lung: validation of new tools for the expression study of retinoid receptors. BMC Cancer 9: 423, 2009.

4. Fujiwara K, Fujimoto N, Tabata M, et al: Identification of epigenetic aberrant promoter methylation in serum DNA is useful for early detection of lung cancer. Clin Cancer Res 11: 1219-1225, 2005.

5. Hsu HS, Chen TP, Hung CH, et al: Characterization of a multiple epigenetic marker panel for lung cancer detection and risk assessment in plasma. Cancer 110: 2019-2026, 2007.

6. Grote HJ, Schmiemann V, Geddert H, et al: Aberrant promoter methylation of p16(INK4a), RARB2 and SEMA3B in bronchial aspirates from patients with suspected lung cancer. Int J Cancer 116: 720-725, 2005.

7. Herman JG, Graff JR, Myohanen S, Nelkin BD and Baylin SB: Methylation-specific PCR: a novel PCR assay for methylation status of CpG islands. Proc Natl Acad Sci USA 93: 9821-9826, 1996.

8. Belinsky SA, Liechty KC, Gentry FD, et al: Promoter hypermethylation of multiple genes in sputum precedes lung cancer incidence in a high-risk cohort. Cancer Res 66: 3338-3344, 2006.

9. Ushijima T, Nakajima T and Maekita T: DNA methylation as a marker for the past and future. J Gastroenterol 41: 401-407, 2006.

10. Ikoma H, Ichikawa D, Daito I, et al: Clinical application of methylation specific-polymerase chain reaction in serum of patients with gastric cancer. Hepatogastroenterology 54: 946-950, 2007

11. Bu P and Wan YJ: Fenretinide-induced apoptosis of Huh-7 hepatocellular carcinoma is retinoic acid receptor beta dependent. BMC Cancer 7: 236, 2007.

12. Choi CH, Lee KM, Choi JJ, et al: Hypermethylation and loss of heterozygosity of tumor suppressor genes on chromosome $3 \mathrm{p}$ in cervical cancer. Cancer Lett 255: 26-33, 2007.

13. Jin Y, Xu H, Zhang C, et al: Combined effects of cigarette smoking, gene polymorphisms and methylations of tumor suppressor genes on non small cell lung cancer: a hospital-based case-control study in China. BMC Cancer 10: 422, 2010.

14. Brabender J, Metzger R, Salonga D, et al: Comprehensive expression analysis of retinoic acid receptors and retinoid $\mathrm{X}$ receptors in non-small cell lung cancer: implications for tumor development and prognosis. Carcinogenesis 26: 525-530, 2005.

15. Vuillemenot BR, Pulling LC, Palmisano WA, Hutt JA and Belinsky SA: Carcinogen exposure differentially modulates RAR-beta promoter hypermethylation, an early and frequent event in mouse lung carcinogenesis. Carcinogenesis 25: 623-629, 2004.

16. Jarmalaite S, Kannio A, Anttila S, Lazutka JR and Husgafvel-Pursiainen K: Aberrant p16 promoter methylation in smokers and former smokers with nonsmall cell lung cancer. Int J Cancer 106: 913-918, 2003. 
17. Kim DH, Kim JS, Ji YI, et al: Hypermethylation of RASSF1A promoter is associated with the age at starting smoking and a poor prognosis in primary non-small cell lung cancer. Cancer Res 63: 3743-3746, 2003.

18. Pulling LC, Vuillemenot BR, Hutt JA, Devereux TR and Belinsky SA: Aberrant promoter hypermethylation of the death-associated protein kinase gene is early and frequent in murine lung tumors induced by cigarette smoke and tobacco carcinogens. Cancer Res 64: 3844-3848, 2004.
19. Yanagawa N, Tamura G, Oizumi H, Takahashi N, Shimazaki Y and Motoyama T: Frequent epigenetic silencing of the p16 gene in non-small cell lung cancers of tobacco smokers. Jpn J Cancer Res 93: 1107-1113, 2002.

20. Toulouse A, Morin J, Dion PA, Houle B and Bradley WE: RARbeta2 specificity in mediating RA inhibition of growth of lung cancer-derived cells. Lung Cancer 28: 127-137, 2000. 